\title{
COMPARATIVE ANALYSIS OF THE RELEASE PERFORMANCE OF INDOMETHACIN FROM TRANSDERMAL THERAPEUTIC SYSTEMS
}

\author{
PAULA ANTONOAEA ${ }^{1}$, MAGDALENA BÎRSAN $^{2 *}$, NICOLETA TODORAN $^{1}$, EMÖKE RÉDAI $^{1}$, \\ ROBERT ALEXANDRU VLAD ${ }^{1}$, DANIELA-LUCIA MUNTEAN ${ }^{3}$, AURA RUSU ${ }^{4}$, ADRIANA \\ CIURBA $^{1}$
}

1 "George Emil Palade” University of Medicine, Pharmacy, Science and Technology of Târgu Mureș, Faculty of Pharmacy, Department of Pharmaceutical Technology and Cosmetology, 38 Gheorghe Marinescu Street, 540139, Târgu Mureș, Romania

2 "Grigore T. Popa" University of Medicine and Pharmacy, Faculty of Pharmacy, Department of Pharmaceutical

Technology, 16 Universitatii Street, 700115, Iași, Romania

3 “George Emil Palade” University of Medicine, Pharmacy, Science and Technology of Târgu Mureș, Faculty of Pharmacy, Department of Analytical Chemistry and Drug Analysis, 38 Gheorghe Marinescu Street, 540139, Târgu Mureș, Romania

4 "George Emil Palade" University of Medicine, Pharmacy, Science and Technology of Târgu Mureș, Faculty of Pharmacy, Department of Pharmaceutical Chemistry, 38 Gheorghe Marinescu Street, 540139, Târgu Mureș, Romania

*corresponding author: magdalena.birsan@umfiasi.ro

Manuscript received: February 2020

\begin{abstract}
By their advantages, transdermal therapeutic systems (TTSs) represent an alternative to the conventional pharmaceutical forms. In this study, 3 formulations of TTSs with indomethacin (IND) were developed, which were subjected to analysis by model-independent (by calculation of the $f_{1}$ and $f_{2}$ factors; linearization by simple regression), respectively model-dependent methods (modelling with Higuchi function). Release evaluation of the IND was performed using the Franz diffusion cell method through a synthetic or biological membrane, at $\mathrm{pH} 5.5$ and $\mathrm{pH}$ 7.4. The obtained results showed that although differences were observed between the analysed release profiles, at an evaluation of the $f_{2}$ factors there were observed similarities in the shapes of the release curves. By simple linear regression it was determined the diffusion flux through the membranes, which varied depending on the $\mathrm{pH}$ and on the type of membrane: $0.749-80.270 \mu \mathrm{g} / \mathrm{cm}^{2} \mathrm{~h}$. The $\mathrm{R}^{2}<1$ values denote the influence of the ingredients in the IND release. Under certain experimental conditions, the $\mathrm{IND}_{3}$ formulation maintains the steady state for 28 hours at $\mathrm{pH} 5.5$, respectively 12 hours at $\mathrm{pH} 7.4$.
\end{abstract}

\section{Rezumat}

Datorită avantajelor pe care le conferă, sistemele terapeutice transdermice (STT) reprezintă o alternativă la formele farmaceutice convenţionale. În acest studiu s-au dezvoltat 3 formulări de STT cu indometacin (IND), care au fost supuse analizei prin metode model-independente (calcularea factorilor $f_{l}$ și $f_{2}$; liniarizarea prin regresie simplă), respectiv modeldependente (modelare cu funcția Higuchi). Evaluarea cedării IND s-a realizat prin metoda cu celula difuzimetrică Franz, studiul efectuându-se prin membrană sintetică sau biologică, la pH 5,5 și pH 7,4. Rezultatele obținute au arătat că deși au fost observate diferențe între curbele de cedare analizate, la o evaluare a factorilor $f_{2} \mathrm{~s}$-a observat o similaritate în alura curbelor de cedare. Prin liniarizarea prin regresie simplă s-a determinat fluxul prin membrane, care a variat în funcţie de $\mathrm{pH}$ şi de tipul membranei: $0,749-80,270 \mu \mathrm{g} / \mathrm{cm}^{2} \mathrm{~h}$. Valorile $\mathrm{R}^{2}<1$ denotă influenţa ingredientelor în cedarea IND. În anumite condiții experimentale, formularea $\mathrm{IND}_{3}$ menține starea de echilibru 28 ore la $\mathrm{pH}$ 5,5, respectiv 12 ore la $\mathrm{pH}$ 7,4.

Keywords: indomethacin, transdermal systems, diffusion flux, release profile

\section{Introduction}

Administration of a drug by the transdermal route can be used for pain treatment when oral administration intolerance occurs (dysphagia, constipation). In this way, a safer administration is ensured [2, 4, 5, 18], especially for the patients who cannot administer themselves the doses of the non-steroidal antiinflammatory drugs (NSAIDs) like indomethacin, diclofenac, meloxicam etc. [22, 23]. It is well known that the NSAIDs, by their mechanism of action, are decreasing the pain which can appear in rheumatic diseases when are administered orally repeatedly, but the gastric side effects can also occur [12, 22]. Recent studies showed that over 30 millions of people are using substances from this class of drugs, $40 \%$ being over 65 years old $[6,14]$. Indomethacin (IND) belongs to the NSAIDs class often used in inflammatory pathologies. To decrease the side effects of the NSAIDs, and especially of the IND, and taking into consideration the percentage of people that needs this type of medication, the development of transdermal therapeutic systems (TTSs) can bring a considerable interest due to the ease of administration. The diffusion process of an active substance from the matrix type 
TTS is a complex process, characterized by the mobilization of the drug molecules through the polymeric chains of the matrix when it is applied on the skin. In experimental conditions, similar to the physiological ones, this passive process is followed by releasing of the drug from the polymeric matrix and by crossing the test membrane. On the other hand, the availability of a drug from TTS is influenced by the independent variable "time" and also by the formulation and testing variables $[1,2,9,16]$. The aim of the study consists of a comparative analysis of the releasing profiles of IND from TTSs, using mathematical models.

\section{Materials and Methods}

\section{Chemicals}

The pharmaceutical substances used in the study were: indomethacin - IND (Sigma Aldrich Milano, Italy), hydroxypropyl methyl cellulose 15000 - HPMC 15000 (Shin-Etsu Chemical Co., Ltd. Tokyo, Japan), hydroxypropyl methyl cellulose E5 - HPMC E5 $_{\text {(Dow Chemical }}$ Co., Midland, USA), propylene glycol - PG (Scharlau Chemie, Barcelona, Spain), ethanol (Chemical Comp., Romania), Tween 20 - Tw 20 (Sigma Aldrich Milano, Italy). Ultrapure water was prepared with a Millipore Direct QS distiller. All other reagents and solvents were of analytical grade.

\section{Preparation of the indomethacin TTSS}

In this study three compositions of IND TTSs were obtained (Table I) by solvent evaporation technique $[13,20]$.

Table I

Compositions of the proposed formulations

\begin{tabular}{|c|c|c|c|}
\hline Compositions $\left(\mathrm{mg} / 2.54 \mathrm{~cm}^{2}\right)$ & $\overline{\text { IND }_{1}}$ & $\overline{\text { IND }_{2}}$ & $\overline{\text { IND }_{3}}$ \\
\hline & \multicolumn{3}{|c|}{ Drug } \\
\hline \multirow[t]{2}{*}{ IND } & 3.37 & 3.37 & 3.37 \\
\hline & \multicolumn{3}{|c|}{ Polymers } \\
\hline HPMC $_{E 5}$ & 20.20 & - & - \\
\hline \multirow[t]{2}{*}{$\mathrm{HPMC}_{15000}$} & - & 6.70 & 10.10 \\
\hline & \multicolumn{3}{|c|}{ Other excipients } \\
\hline Alcohol & 200 & 200 & 200 \\
\hline PG & 70 & 70 & 70 \\
\hline Tween $_{20}$ & 20 & 20 & 20 \\
\hline Ultrapure water & 370 & 390 & 380 \\
\hline
\end{tabular}

\section{In vitro drug released studies}

Release studies were carried out at $32 \pm 0.5^{\circ} \mathrm{C}$ using the Franz diffusion cell (FDC) (Hanson Research) with an available diffusion area of $2.5434 \mathrm{~cm}^{2}$ and $14 \mathrm{~mL}$ of the receptor compartment placed on a magnetic stirrer (300 RPM). The acceptor media were phosphate buffer solutions at $\mathrm{pH} 5.5$ and $\mathrm{pH} 7.4$. Drug release studies were performed on two types of membranes: nylon type synthetic membrane (SM): $25 \mathrm{~mm}$ diameter, $0.45 \mu \mathrm{m}$ thickness, Teknokroma, and biological membrane: pig ear skin (BM) with a thickness $<1 \mathrm{~mm}$. Biological membranes require a special treatment $[11,22]$. Excess fat was removed and hairless pig ear skin was stored in a freezer at $-26^{\circ} \mathrm{C}$ for less than six months. Before starting the release studies each membrane was equilibrated for 30 minutes in the dissolution medium. The SM was placed between the compartments of the FDC. The pig ear skin pieces were placed over the FDC with the epidermal side in contact with the donor compartment. IND patches with $2.54 \mathrm{~cm}^{2}$ surface were subsequently applied to the membrane in the donor compartment and covered with parafilm to avoid evaporation. Samples of definite volume $(1 \mathrm{~mL})$ were withdrawn at regular intervals from the receptor compartment followed by replacement with equal volume of fresh medium solution. The samples were analysed using a HPLC Agilent Technologies 1100 Series (USA) at a wavelength of $320 \mathrm{~nm}$.

Analysis methods of the release profiles

For drug release studies, the diffusion flux was calculated at steady state from the slope of the straight portion of the curve. The obtained results were fitted into the Higuchi model by using DDSolver Add-In Program software. By pairwise procedure method two parameters were calculated: $f_{l}$ (difference factor) and $f_{2}$ (similarity factor), using the equations [24]:

$$
f_{1}=\left\{\left[\sum_{t=1}^{n}\left|R_{t}-T_{t}\right|\right] /\left[\sum_{t=1}^{n} R_{t}\right]\right\} \cdot \mathbf{1 0 0}
$$

where: $f_{l}$ expresses $\%$ of the differences calculated for each point of the two curves and it is the measurement of the relative error between two release profiles compared. When the dissolution profile using the tested formulation and the reference one are the same, $f_{l}$ has zero value and it increases with the dissimilarity of the analyzed formulas $[9,19]$.

$$
f_{2}=50 \cdot \log \left\{\left[1+(1 / n) \sum_{t=1}^{n}\left(R_{t}-T_{t}\right)^{2}\right]^{-0.5} \cdot 100\right.
$$

where: $f_{2}$ expresses $\%$ of the similarity of the two curves and it can be used frequently for comparison of the release profiles of the oral solid pharmaceutical forms $[3,10,26]$. When two release profiles of the active ingredient are the same, $f_{2}=50-100[10,13$, 20]; $n$ is the number of the determination times; $R_{t}$ the average release percentage from the reference drug at time $t$ after the initiation of the test; $T_{t}$ - the average percentage from the drug tested, dissolved at time $t$ after the initiation of the test.

\section{Results and Discussion}

Results of the in vitro drug release studies of transdermal patches of $\mathrm{IND}_{1}, \mathrm{IND}_{2}$ and $\mathrm{IND}_{3}$ are presented in Figures 1 - 4. The release profiles were obtained by plotting the cumulative amount of IND per area permeated against time. 
FARMACIA, 2020, Vol. 68, 6

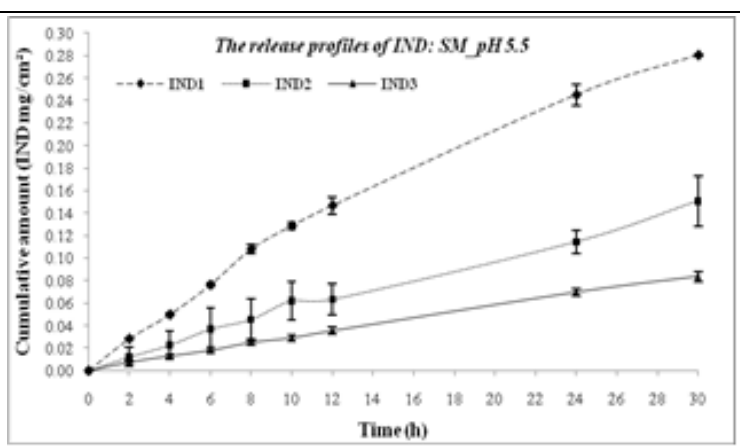

Figure 1.

The release profiles of IND through synthetic membrane at $p H 5.5$

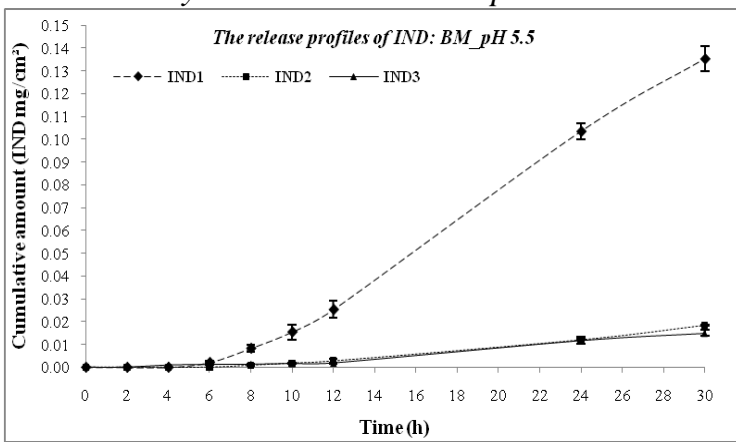

Figure 3.

The release profiles of IND through biological membrane at $\mathrm{pH} 5.5$

The diffusion flux of IND at steady state across the tested membranes was calculated by linear regression from the slope of the curve on the linear portion. Kinetic analysis was performed with Higuchi- $\mathrm{T}_{\mathrm{lag}}$ and Higuchi- $\mathrm{F}_{0}$ mathematical models (model-dependent method) which were applied on the curve portion corresponding to the IND released between 2 - 30 hours. Results of diffusion flux of IND through SM and $\mathrm{BM}$ and kinetic mathematical models analysis are shown in Table II and Table III.

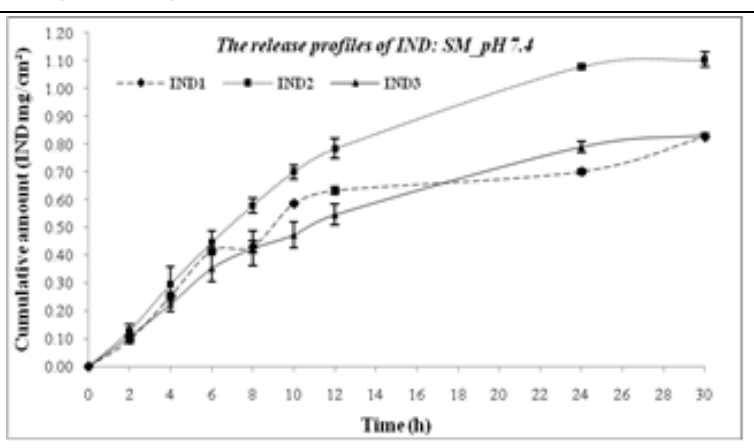

Figure 2.

The release profiles of IND through synthetic membrane at $\mathrm{pH} 7.4$

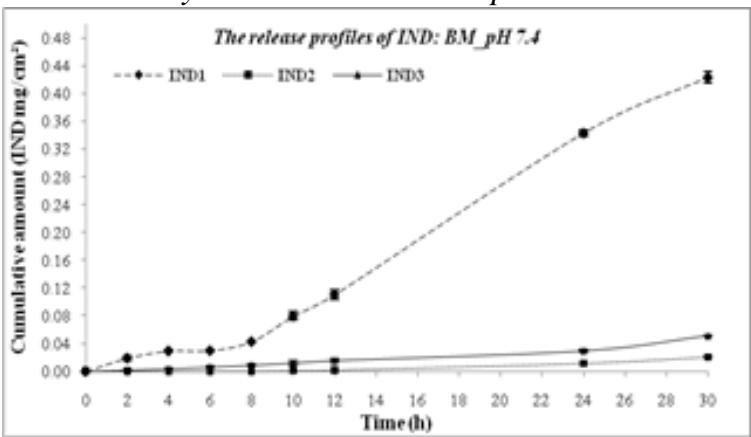

Figure 4.

The release profiles of IND through biological membrane at $\mathrm{pH} 7.4$

Different values of IND diffusion flow show that each TTS had a particular behaviour, dependent on the $\mathrm{pH}$, on the tested membranes type and also on the composition of the polymer matrix. Diffusion flow values varied between: $0.749-80.270 \mu \mathrm{g} / \mathrm{cm}^{2} \mathrm{~h}$, the lowest flow being observed for the formulation $\mathrm{IND}_{2}$ through $\mathrm{BM}$ at $\mathrm{pH} 5.5$, and the highest flow was observed for the formulation $\mathrm{IND}_{1}$ through $\mathrm{SM}$ at $\mathrm{pH}$ 7.4.

Table II

IND release kinetics - SM

\begin{tabular}{|c|c|c|c|c|c|c|c|}
\hline \multicolumn{3}{|c|}{$\overline{\text { SM }}$} & \multicolumn{2}{|c|}{ pH 5.5} & \multicolumn{3}{|c|}{ pH 7.4 } \\
\hline \multicolumn{2}{|c|}{ Formula } & IND $_{1}$ & $\mathrm{IND}_{2}$ & IND $_{3}$ & IND $_{1}$ & $\mathrm{IND}_{2}$ & IND $_{3}$ \\
\hline \multicolumn{2}{|c|}{$\begin{array}{c}\text { Diffusion flux } \\
\mathrm{J}\left(\mu \mathrm{g} / \mathrm{cm}^{2} \mathrm{~h}\right) \pm \mathrm{SD} \\
\end{array}$} & $\begin{array}{r}14.530 \\
\pm 0.750 \\
\end{array}$ & $\begin{array}{c}6.183 \\
\pm 0.515 \\
\end{array}$ & $\begin{array}{c}2.749 \\
\pm 0.033 \\
\end{array}$ & $\begin{array}{l}80.270 \\
\pm 0.665 \\
\end{array}$ & $\begin{array}{r}70.940 \\
\pm 2.291 \\
\end{array}$ & $\begin{array}{r}31.340 \\
\pm 1.734 \\
\end{array}$ \\
\hline \multirow{2}{*}{ Steady state } & $t_{i}(h)$ & 4.05 & 2.10 & 2.10 & 2.10 & 4.05 & 6.00 \\
\hline & $\mathrm{t}_{\mathrm{f}}(\mathrm{h})$ & 7.95 & 5.85 & 30.00 & 5.85 & 7.95 & 12.00 \\
\hline
\end{tabular}

Higuchi with $\mathbf{T}_{\text {lag: }}: \mathrm{F}=\mathrm{k}_{\mathrm{H}} *\left(\mathrm{t}-\mathrm{Tl}_{\mathrm{ag}}\right)^{0.5} ;\left(\mathrm{k}_{\mathrm{H}}\right.$ : Higuchi release constant; $\mathrm{T}_{\text {lag: }}$ lag time prior to drug release; $\mathrm{R}^{2}$ : correlation coefficient)

\begin{tabular}{|c|c|c|c|c|c|c|}
\hline $\mathrm{kH}_{\mathrm{H}}$ & 51.333 & 26.203 & 14.957 & 157.222 & 216.063 & 158.944 \\
\hline $\mathrm{T}_{\text {lag }}(\mathrm{h})$ & 3.355 & 4.196 & 4.483 & 1.333 & 1.804 & 1.822 \\
\hline $\mathrm{R}^{2}$ & 0.9377 & 0.9378 & 0.9388 & 0.9667 & 0.9567 & 0.9560 \\
\hline
\end{tabular}

Higuchi with $\mathbf{F}_{0}: \mathrm{F}=\mathrm{F}_{0}+\mathrm{kH}_{\mathrm{H}} \mathrm{t}^{0.5} ;\left(\mathrm{F}_{\mathrm{o}}\right.$ : initial fraction of the drug in the solution resulting from a burst release)

\begin{tabular}{|c|c|c|c|c|c|c|}
\hline $\mathrm{k}_{\mathrm{H}}$ & 67.201 & 34.875 & 20.116 & 178.953 & 262.334 & 193.672 \\
\hline $\mathrm{F}_{0}\left(\mu \mathrm{g} / \mathrm{cm}^{2}\right)$ & | & - & - & 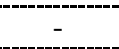 & - & - \\
\hline $\mathrm{R}^{2}$ & 0.9788 & 0.9788 & 0.9788 & 0.9788 & 0.9788 & 0.9788 \\
\hline
\end{tabular}


IND release kinetics - BM

\begin{tabular}{ccccc|ccc}
\hline \multicolumn{1}{c}{ BM } & \multicolumn{3}{c|}{ pH 5.5 } & \multicolumn{3}{c}{ pH 7.4 } \\
\hline Formula & IND $_{\mathbf{1}}$ & IND $_{\mathbf{2}}$ & IND $_{\mathbf{3}}$ & IND $_{\mathbf{1}}$ & IND $_{\mathbf{2}}$ & IND $_{\mathbf{3}}$ \\
\hline Diffusion flux & 6.357 & 0.749 & 0.709 & 18.850 & 0.776 & 1.277 \\
$\mathrm{~J}\left(\mu \mathrm{g} / \mathrm{cm}^{2} \mathrm{~h}\right) \pm \mathrm{SD}$ & \pm 0.194 & \pm 0.035 & \pm 0.048 & \pm 0.342 & \pm 0.051 & \pm 0.036 \\
\hline \multirow{2}{*}{ Steady state } & $\mathrm{t}_{\mathrm{i}}(\mathrm{h})$ & 10.05 & 10.05 & 10.05 & 8.10 & 10.05 & 2.10 \\
\cline { 2 - 8 } & $\mathrm{t}_{\mathrm{f}}(\mathrm{h})$ & 24.00 & 24.00 & 30.00 & 24.00 & 24.00 & 24.00 \\
\hline \multicolumn{3}{c}{ Kinetic analysis } \\
\hline
\end{tabular}

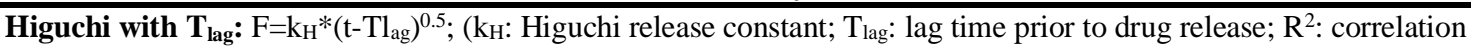

\begin{tabular}{c|c|c|c|c|c|c}
\hline \multicolumn{1}{c}{ coefficient $)$} \\
\hline $\mathrm{k}_{\mathrm{H}}$ & 24.093 & 3.119 & 2.652 & 76.516 & 3.300 & 8.232 \\
\hline $\mathrm{T}_{\operatorname{lag}}(\mathrm{h})$ & 8.269 & 8.548 & 7.983 & 7.278 & 9.103 & 6.438 \\
\hline $\mathrm{R}^{2}$ & 0.9596 & 0.9607 & 0.9580 & 0.9542 & 0.9625 & 0.9491 \\
\hline
\end{tabular}

Higuchi with $\mathbf{F}_{\mathbf{0}}: \mathrm{F}=\mathrm{F}_{0}+\mathrm{k}_{\mathrm{H}}{ }^{* 0.5} ;\left(\mathrm{F}_{\mathrm{o}}\right.$ : initial fraction of the drug in the solution resulting from a burst release)

\begin{tabular}{c|c|c|c|c|c|c}
\hline $\mathrm{k}_{\mathrm{H}}$ & 34.634 & 4.479 & 3.789 & 108.285 & 4.713 & 11.472 \\
\hline $\mathrm{F}_{0}\left(\mu \mathrm{g} \cdot \mathrm{cm}^{-2}\right)$ & - & - & - & - & - & - \\
\hline $\mathrm{R}^{2}$ & 0.9698 & 0.9672 & 0.9732 & 0.9776 & 0.9614 & 0.9788 \\
\hline
\end{tabular}

One limiting factor of the IND diffusion flow through the tested membranes was the $\mathrm{pH}$ of the acceptor media. It can be noticed a significantly higher flow (up to 20 times higher) at $\mathrm{pH} 7.4$ vs. $\mathrm{pH} 5.5$. A second limiting factor was the type of membrane. It was seen for all the proposed TTSs that the flow values obtained through the biological membrane are lower than those through the synthetic membrane. The differences between the flow values can also be assigned to the type of polymeric matrices. Higher flow values were observed for the formulations which contain a low viscosity polymer - HPMC $\mathrm{E}_{\mathrm{E}}$ compared to the formulations with a high viscosity polymer $\mathrm{HPMC}_{15000 \text {. }}$

The Higuchi model characterizes the kinetic release process of the substances which are water-soluble or sparingly soluble incorporated into solid or semisolid matrices and is indicated to describe the diffusion process of the drugs from transdermal systems [7, $8,17,27]$.

Under certain experimental conditions, the proposed formulations of TTSs may maintain the steady state

for a more extended period of time. We can assign a particular note to the $\mathrm{IND}_{3}$ formulation which, under skin-like $\mathrm{pH}$ conditions and through $\mathrm{SM}$, reaches the steady state in 2 hours and maintains it for 28 hours. At $\mathrm{pH} 7.4$, through BM, the steady state is maintained for 12 hours. These results suggest that it is possible to optimize the kinetic parameters calculated by modelling with the Higuchi function. In this way it is possible to increase the flow of IND through the membranes and at the same time, the steady state can be maintained for at least 12 hours. A well-known approach used to evaluate the kinetic release of IND from TTSs is a model independent method which analyses two factors: $f_{1}$ - difference factor and $f_{2}$ - similarity factor.

To evaluate the release profiles of IND from the proposed formulations, a similar product with indomethacin was chosen as reference (Ref). The statistical results obtained by comparing the data of the Ref with the data of the formulations tested in the study are presented in Table IV.

Table IV

Results of in vitro dissolution profile comparison

\begin{tabular}{|c|c|c|c|c|c|c|}
\hline & \multicolumn{6}{|c|}{ Values of difference factor $f_{1}$ and similarity factor $f_{2}$} \\
\hline & & & $f_{l}$ & $f_{2}$ & $f_{1}$ & $f_{2}$ \\
\hline & Reference & Test & \multicolumn{2}{|c|}{ SM } & \multicolumn{2}{|c|}{$\mathrm{BM}$} \\
\hline \multirow{3}{*}{ pH 5.5} & Ref & $\mathrm{IND}_{1}$ & 149 & 59 & 821 & 70 \\
\hline & Ref & $\mathrm{IND}_{2}$ & 19 & 94 & 15 & 99 \\
\hline & Ref & $\mathrm{IND}_{3}$ & 33 & 85 & 20 & 98 \\
\hline \multirow{3}{*}{$\mathrm{pH} 7.4$} & Ref & $\mathrm{IND}_{1}$ & 121 & 61 & 72 & 65 \\
\hline & Ref & $\mathrm{IND}_{2}$ & 23 & 74 & 94 & 52 \\
\hline & Ref & $\mathrm{IND}_{3}$ & 34 & 68 & 80 & 54 \\
\hline
\end{tabular}

Model independent approaches are represented by the calculation of the factors $f_{1}$ and $f_{2}$. Their values, calculated with DDSolver Add-In Program software, show a different behavior of the release profiles of the drug from the tested formulations. These aspects can be explained by the formulation variables such as: type of the polymer used and also the concentration of the polymer. Small differences can be seen in the 
values of $f_{2}$ factors obtained for the formulas $\mathrm{IND}_{2}$ and $\mathrm{IND}_{3}$, formulas that differ through the $\mathrm{HPMC}_{15000}$ concentration. On the other hand, it has been observed that at $\mathrm{pH} 5.5$ and also at $\mathrm{pH} 7.4$ were obtained values of the $f_{1}$ factors higher than 15 . These values show a different allure of the releasing curves as a result of the influences of the formulations variables. Despite that, because values of the $f_{2}$ factors are between 50 and 100, we can conclude that there is a similarity between them.

The differences between the values of the factors $f_{l}$ and $f_{2}$ also suggest the influence of the membrane type used during the study (synthetic or biological).

This influence was obvious for the determinations realised at the $\mathrm{pH} 7.4$ and also at $\mathrm{pH}$ 5.5.

To estimate the relationship between the quantities of drug released (dependent variable) and time (independent variable) it was applied the linearization of the curves using simple regression. For the statistical analysis of the individual curves were followed the modifications of the correlation coefficients $R^{2}[25,27]$ and the significance of the differences between the regression line. The results of the linearization using simple regression are presented in Table V.

Table V

Results of linearization by simple regression

\begin{tabular}{|c|c|c|c|c|}
\hline & \multicolumn{4}{|c|}{ Linearization by simple regression } \\
\hline pH & Membrane & Formula & Straight equation & $\mathbf{R}^{2}$ \\
\hline \multirow{6}{*}{ pH 5.5} & \multirow{3}{*}{ SM } & $\mathrm{IND}_{1}$ & $y=0.6998 x+1.4400$ & 0.9783 \\
\hline & & $\mathrm{IND}_{2}$ & $y=0.3632 x+0.3770$ & 0.9913 \\
\hline & & $\mathrm{IND}_{3}$ & $\mathrm{y}=0.2095 \mathrm{x}+0.1240$ & 0.9987 \\
\hline & \multirow{3}{*}{$\mathrm{BM}$} & $\mathrm{IND}_{1}$ & $y=0.3681 x-1.4980$ & 0.9447 \\
\hline & & $\mathrm{IND}_{2}$ & $\mathrm{y}=0.0479 x-0.2093$ & 0.9280 \\
\hline & & $\mathrm{IND}_{3}$ & $\mathrm{y}=0.0400 \mathrm{x}-0.1440$ & 0.9285 \\
\hline \multirow{6}{*}{ pH 7.4} & \multirow{3}{*}{ SM } & $\mathrm{IND}_{1}$ & $y=1.8640 x+13.080$ & 0.8001 \\
\hline & & $\mathrm{IND}_{2}$ & $y=2.7320 x+13.720$ & 0.8818 \\
\hline & & $\mathrm{IND}_{3}$ & $\mathrm{y}=2.0170 \mathrm{x}+9.9230$ & 0.9094 \\
\hline & \multirow{3}{*}{ BM } & $\mathrm{IND}_{1}$ & $y=1.3100 x-3.0300$ & 0.9642 \\
\hline & & $\mathrm{IND}_{2}$ & $y=0.0512 x-0.2526$ & 0.8830 \\
\hline & & $\mathrm{IND}_{3}$ & $\mathrm{y}=0.1195 \mathrm{x}-0.1995$ & 0.9601 \\
\hline
\end{tabular}

The strong dependence between the amount of released drug and time is based on the values of coefficient $\mathrm{R}^{2}$ and the positive correlation indicated by the positive values of the regression slopes. The values of the coefficient $\mathrm{R}^{2}$ have variations between 0.8001 - 0.9987, which suggests the fact that there are also other factors that influence the releasing of the drug from the obtained TTSs. The composition variability is one of the most critical factors which discriminates the proposed formulations in the study. The sorts of cellulose-derived polymers selected as film formers had a discriminant role in the release process. Variability of the results can be correlated with their physical and chemical properties. Based on the results acquired, we can conclude that there is a directly proportional relation between the viscosity of the polymers, their concentration and the influence that they had over the amount of IND released from the proposed formulations.

The release rate of the drug formulated as TTS can be directly influenced by a physical factor such as the hydration degree of the polymeric matrix as a result of the occlusion of the TTS in the upper part, which occurs in the administration moment. A consequence of this phenomenon consists in the transformation of the polymeric matrix in a gel form, favouring the drug molecules migration through the polymeric chain. Also, in this stage, the entire complex of excipients can have an essential role because of the bonds that are being established between them and the active ingredient.

Results of the correlation coefficients also suggest that the release rate of IND is controlled by the $\mathrm{pH}$ of the acceptor media. With only few exceptions it can be observed that the $\mathrm{R}^{2}$ values were higher at a $\mathrm{pH}$ of 5.5 compared to the $\mathrm{pH}$ of 7.4. This fact can indicate that at a $\mathrm{pH}$ similar to the blood, the drug concentration released is less influenced by the composition of the formulations or by the diffusion process. Also, the higher viscosity of $\mathrm{HPMC}_{15000}$ could determine the prolonged retention of the active ingredient molecules between the polymeric chains ("more dense molecular chain").

\section{Conclusions}

The availability of the IND from the proposed TTSs formulations is influenced by the formulation variables and also by the testing conditions. In comparison with a reference product, the values of the difference factors $\left(f_{1}>15\right)$ showed that there are differences between all the three formulations proposed, but the importance of the similarity factors $f_{2}$ between 50 and 100 suggested that there is a similarity between the allure of the releasing curves.

Linearization using simple regression of the releasing profiles has allowed the calculation of the $\mathrm{R}^{2}$. With 
the exception of the time influence, the obtained parameters conducted to the conclusion that the amount of released drug is also influenced by other factors such as the variability of compositions and experimental conditions.

Linear regression analysis is correlated with the release rate of IND from the TTSs. We can conclude that the $\mathrm{pH}$ of the acceptor media exerts a significant influence on the release rate of the drug, at a $\mathrm{pH}$ of 7.4 the release rate of the IND being much higher than at $\mathrm{pH}$ 5.5. The particularities of each testing membrane conducted to the conclusion that the release rate of the drug is influenced directly by this variable, observing a decrease of the release rate as follows: $\mathrm{SM}<\mathrm{BM}$. The release rate of the IND from the TTS was directly influenced by the type of polymeric matrix which conducts to the conclusion that it decreases with the increasing polymer viscosity. In conclusion, the $\mathrm{pH}$ of the acceptor media, type of tested membranes, the sorts of HPMC and their concentration in the proposed formulations, had a direct influence on the release profile of IND from hydrated TTSs matrices type.

\section{Acknowledgement}

This work was supported by the University of Medicine, Pharmacy, Science and Technology "George Emil Palade" of Târgu Mureș, Research Grant no. 275/6/11.01.2017.

\section{Conflict of interest}

The authors declare no conflict of interest.

\section{References}

1. Abd E, Yousuf SA, Pastore MN, Telaprolu K, Mohammed YH, Namjoshi S, Grice JE, Roberts MS, Skin models for the testing of transdermal drugs. Clinic Pharmacol: Adv Applic., 2016; 8: 163-176.

2. Akram MR, Ahmad M, Abrar A, Sarfraz RM, Mahmood A, Formulation design and development of matrix diffusion controlled transdermal drug delivery of glimepiride. Drug Design, Development and Therapy, 2018;12: 349-364.

3. Anand $\mathrm{O}, \mathrm{Yu}$ LX, Conner DP, Davit BM, Dissolution Testing for Generic Drugs: An FDA Perspective. AAPS Journal, 2011; 13 (3): 328-335.

4. Bîrsan M, Apostu M, Todoran N, Antonoaea P, Rusu A, Ciurba A, Development of Dermal Films Containing Miconazole Nitrate. Molecules, 2018; 23 (7): 1-12.

5. Bîrsan M, Cristofor AC, Antonoaea P,Todoran N, Bibire N, Panainte AD, Vlad RA, Grigore M, Ciurba A, Evaluation of miconazole nitrate permeability through biological membrane from dermal systems. Farmacia, 2020; 68(1): 111-115.

6. Brown CK, Friedel HD, Barker AR, Buhse LF, Keitel S, Cecil TL, Kraemer J, Morris JM, Reppas C, Stickelmeyer MP, Yomota C, Shah VP, FIP/AAPS Joint Workshop Report: Dissolution/In Vitro Release
Testing of Novel/Special Dosage Forms. Indian J Pharm Sci., 2011; 73(3): 338-353.

7. Ciurba A, Todoran N, Tăurean A, Antonoaea P, Hancu G, Moisei A, Sipos E, Kinetic analysis of in vitro drug release from valproic acid and sodium valproate suppositories. Farmacia, 2014; 62(6): 1143-1156.

8. Dash S, Murthy PN, Nath L, Chowdhury P, Kinetic modeling on drug release from controlled drug delevery systems. Acta Poloniae Pharmaceutica Drug Res., 2010; 67(3): 217-223.

9. $* * *$ Guidance for Industry - Dissolution Testing of Immediate Release Solid Oral Dosage Forms, U.S. Department of Health and Human Services, Food and Drug Administration, Center for Drug Evaluation and Research (CDER), August 1997: 8.

10. ***Guidance for Industry - Waiver of In Vivo Bioavailability and Bioequivalence Studies for ImmediateRelease Solid Oral Dosage Forms Based on a Biopharmaceutics Classification System, U.S. Department of Health and Human Services, Food and Drug Administration, Center for Drug Evaluation and Research (CDER), August 2000 BP.

11. Jacobi U, Kaiser M, Toll R, Mangelsdorf S, Audring H, Otberg N, Sterry W, Lademann Porcine ear skin: an in vitro model for human skin. Skin Res Technol., 2007; 13: 19-24.

12. Kumar SV, Tarun P, Kumar TA, Transdermal drug delivery system for non-steroidal anti inflammatory drugs: A review. IAJPR, 2013; 3(4): 3588-3605.

13. Limberg J, Potthast H, Regulatory status on the role of in vitro dissolution testing in quality control and biopharmaceutics in Europe. Biopharm Drug Dispos., 2013; 34: 247-253.

14. Lenik J, Application of PVC in construction of ionselective electrodes for pharmaceutical analysis: a review of polymer electrodes for nonsteroidal, antiInflammatory drugs, in Thakur VK, Thakur MK (eds): Handbook of Polymers for Pharmaceutical Technologies vol 2, Processing and Applications, Scrivener Publishing LLC, USA. 2015; 197, 212-217.

15. Muţ AM, Vlaia L, Coneac G, Olariu I, Vlaia V, Popoiu C, Hîrjău M, Lupuliasa D, Novel topical chitosan/hydroxypropylmethylcellulose - based hydrogels containing fluconazole and sucrose esters. formulation, physicochemical characterization, in vitro drug release and permeation. Farmacia, 2018; 66(1): 59-69.

16. Ramírez-Campos M, Villafuerte-Robles L, Effect of Formulation Variables on Verapamil Hydrochloride Release from Hydrated HPMC Matrices, Rev Soc Quím Méx., 2004; 48: 326-331.

17. Ramteke KH, Dighe PA, Patil SV, Kharat AR, Mathematical Models of Drug Dissolution: A Review, Sch Acad J Pharm., 2014; 3(5): 388-396.

18. Rusu A, Antonoaea P, Ciurba A, Bîrsan M, Hancu G, Todoran N, Development of a rapid capillary zone electrophoresis method to quantify levofloxacin and meloxicam from transdermal therapeutic systems. Studia UBB Chemia, 2019; LXIV(1): 219-231.

19. Siewert M, Dressman J, Brown CK, Shah VP; FIP; AAPS, FIP/AAPS guidelines to dissolution/in vitro release testing of novel/special dosage forms. AAPS PharmSciTech., 2003; 4(1): 43-52. 
FARMACIA, 2020, Vol. 68, 6

20. Shah VP, Tymes NW, Skelly JP, In vitro release profile of clonidine transdermal therapeutic systems and scopolamine patches. Pharm Res., 1989; 6: 346-351.

21. Sohn M, Korn V, Imanidis G, Porcine ear skin as a biological substrate for in vitro testing of sunscreen performance. Skin Pharmacol Physiol., 2015; 28: 31-41.

22. Vasincu A, Ababei DC, Rusu RN, Stanciu GD, Beșchea Chiriac S, Bild V, Effects of aqueous extract of Vernonia Kotschyana Sch.Bip. Ex Walp roots on experimental gastric ulcer in mice. Farmacia, 2019; 67(5): 836-843.

23. Yadav V, Transdermal Drug Delivery system: Review. Int J Pharm Sci Res., 2012; 3(2): 376-382.
24. Zhang Y, Huo M, Zhou J, Zou A, Li W, Yao C, Xie S, DDSolver: an add-in program for modeling and comparison of drug dissolution profiles. The AAPS Journal. 2010; 12(3): 263-271.

25. Luo Z, Liu C, Quan P, Yang D, Zhao H, Wan X, Fang L, Mechanistic insights of the controlled release capacity of polar functional group in transdermal drug delivery system: the relationship of hydrogen bonding strength and controlled release capacity. Acta Pharm Sin B., 2020; 10(5): 928-945.

26. Zuo J, Gao Y, Bou-Charcra N, Löbenberg R, Evaluation of the DDSolver Software Applications. BioMed Res Int., 2014; 2014: 1-9.

27. https://statistics.laerd.com. 